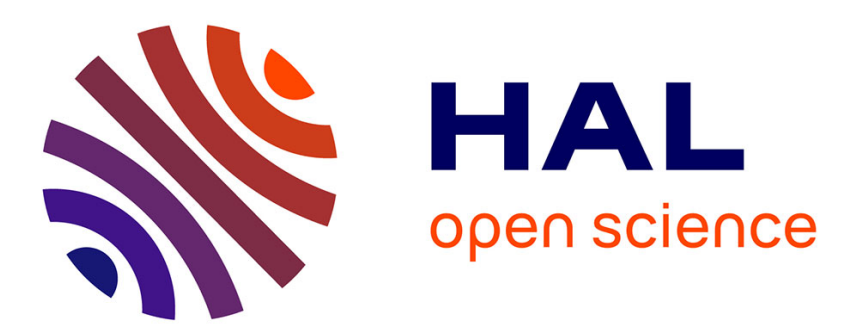

\title{
Mediating Public Issues in Romanian Broadcast Talk: Personalized Communication Strategies
}

Mirela Lazar, Irina Diana Mădroane, Camelia Beciu, Irina Diana Mădroane, Mirela Lazăr

\section{- To cite this version:}

Mirela Lazar, Irina Diana Mădroane, Camelia Beciu, Irina Diana Mădroane, Mirela Lazăr. Mediating Public Issues in Romanian Broadcast Talk: Personalized Communication Strategies. Television and New Media, 2017, 19 (1), pp.75-92. 10.1177/1527476417697270 . hal-02314522

\section{HAL Id: hal-02314522 \\ https://hal.science/hal-02314522}

Submitted on 14 Oct 2019

HAL is a multi-disciplinary open access archive for the deposit and dissemination of scientific research documents, whether they are published or not. The documents may come from teaching and research institutions in France or abroad, or from public or private research centers.
L'archive ouverte pluridisciplinaire HAL, est destinée au dépôt et à la diffusion de documents scientifiques de niveau recherche, publiés ou non, émanant des établissements d'enseignement et de recherche français ou étrangers, des laboratoires publics ou privés. 
Mediating Public Issues in

\title{
Camelia Beciu', Mirela Lazăr', and Irina Diana Mădroane ${ }^{2}$
}

\begin{abstract}
The article examines emerging practices of personalization in political talk shows on Romanian television. Our interest lies in the reconfiguration of the role of critical journalist, as performed by talk show hosts on private TV channels, in the context of increasing commercialization and instrumentalization of the Romanian media in postcommunism. This development consists of the strategic use of personalization, achieved through the talk show dispositive, for the enactment of positions of journalistic interpretation, adversarialness, and intervention on behalf of the citizens. The findings indicate shifts in the symmetry/asymmetry relationships between journalists, guests, politicians, and publics, as well as new ways of constructing and understanding public issues. Two main patterns of personalization have been identified: the journalist as a fully engaged voice, effectively substituting itself for the public opinion, and the journalist as an ordinary person, who has the capacity to see through and expose dominant public discourses.
\end{abstract}

\section{Keywords}

Romanian broadcast journalism, political talk show, personalization, critical journalist, public issue, engaged audience

\footnotetext{
University of Bucharest, Romania

2West University of Timişoara, Romania
}

Corresponding Author:

Mirela Lazăr, Faculty of Journalism and Communication Studies, University of Bucharest, Bucharest 06107I, Romania.

Email: miralazar05@yahoo.com 


\section{Introduction}

Political communication and, in particular, political journalism are currently undergoing intense commercialization and instrumentalization (Hallin and Mancini 2004; Mancini 2011; Van Aelst et al. 2011; Van Santen 2012), known in the literature under labels such as "Foxification" or "entertaining politics." Broadcast journalism is thus characterized by a series of practices that authors attribute to the transition from a model of political journalism based on information, reporting, and deference, to a conversational, personalized, and interpellative model (Stamper and Brants 2011). In the postcommunist Romanian media, such transformations have taken specific, conspicuous forms, the result of a mixture of engaged journalism, spectacle, and celebration of the personal, which can be seen at their most compelling in political talk shows on commercial TV channels (Beciu 2011; Lazăr 2008).

Within this frame, we consider that special scholarly attention is due to the changing role of the journalist from mediator to news celeb (Corner and Pels 2003; Ekström and Patrona 2011; Turner 2009) and, significantly, to a hybridized figure, who alternates "sense-making," "fact-finding," and "fun-making" (de Beus 2011, 26). In other words, the journalist is faced with the challenge of successfully managing two key functions in political journalism, namely, of acting as formally neutral and balanced, and also as a "critical political journalist" (De Smedt and Vandenbrande 2011, 87, emphasis added), who takes an open stance regarding the politicians' actions and statements. In the Romanian public sphere, this posture merges elements from what Christians et al. $(2009,126)$ call the "facilitative role" of the journalist, concerned with granting the public access to and engaging them in debates, and, partially, the "radical role," aimed at social change, including a reform of the Romanian political class; as such, it is strongly geared toward advocacy (Mădroane 2015). A further development in the performance of this hybridized journalistic role is the strategic use of personalization, which, in the Romanian public sphere, stands out among other communication practices.

In the present study, we aim to bring to light underexplored facets of media personalization in connection with the enactment of the status of critical political journalist in talk shows hosted by Romanian commercial televisions. Our claim is that personalization should not be interpreted as a mere discursive strategy or an intensification of the presence of the personal in the public arena, but as a profound reconfiguration of the journalist's role, with significant implications for the construction and understanding of public issues, and for the representation of the public interest. Therefore, the question addressed in this article is not whether personalization dominates a certain media landscape, as we consider this trend embedded in "the postmodern style of political TV talk" (Debrett 2015, 570), or if it is beneficial or detrimental to the quality of political journalism, but how personalization is employed as a resource for the critical journalist and what specific patterns can be encountered in the Romanian televisual culture. Our article is intended as a contribution to the analysis of the personalization of the journalist's role in talk shows (as part of the personalization of the media and the media coverage of politics), and, in correlation, of ensuing ways of audience engagement and 
defining public issues. In what follows, we give a brief overview of the concept of personalization, establishing its relevance for the analysis of the talk show moderator's hybridized figure on Romanian commercial television. We then present our analytical framework, which integrates elements from discursive approaches to the study of personalization into dispositive analysis. Finally, we discuss in detail our findings from the examination of two Romanian political talk shows, after outlining the development of the talk show genre in the postcommunist public sphere.

\section{Personalization in Politics, Media, and Discourse}

Personalization has been the object of numerous studies in political communication and journalism, often concerned with proposing reliable research instruments and operational models that could capture its many facets, assess the extent of its presence in political news content, or consider its effects on voting publics (Jebril et al. 2013; Mancini 2011; Van Aelst et al. 2011; Van Santen 2012). Personalization has also been analyzed from the perspective of the intersection between the political and journalistic fields, for example, to explain political communication models in certain media systems (such as the Mediterranean model proposed by Hallin and Mancini 2004).

The literature commonly mentions two manifestations of personalization, namely, the media focus on individuals instead of political issues and the attention given to the private lives of politicians as opposed to their public performance (Van Aelst et al. 2011, 205, among others), as a starting point for finer distinctions and typologies. Another trend is to discuss personalization as a mechanism of spectacularization of political communication in contemporary democracy, noticeable especially on television (Mancini 2011; Van Santen 2012). If, to some authors, this process is associated with dramatization, celebrification, and media populism in political journalism (Musso 2009; Turner 2009), to others it should be seen as a resource of comprehension, identification, and action for the viewers. In this respect, Coleman (2013) underscores the importance of spectacle in the engagement of publics in debate, as long as it is equally combined with rational deliberation. In discourse studies, Fairclough (1994, 1995), among others, discusses personalization in connection to a larger process of conversationalization, namely, "a restructuring of the boundary between private and public orders of discourse" (Fairclough 1994, 242), which generates hybrid media and political discourses, genres, and identities. Discursively, this is achieved by using "colloquial vocabulary"; "phonic, prosodic and paralinguistic features of colloquial language"; "modes of grammatical complexity characteristic of colloquial spoken language"; "colloquial modes of topical development (as described by conversation analysts)"; and "colloquial genres, such as conversational narrative" (Fairclough 1994, 242; see also Fairclough 1995). More recently, Landert (2014) has proposed a descriptive model for the analysis of personalization in online news, designed to establish various degrees and differences in its realization. According to her, any of the three "entities" in media communication - "news event and news actor," "audience," "text producer," and, occasionally, the "media institution," as a fourth entity - may be personalized on one or more of three interrelated "dimensions." These are the "communicative setting" 
(ranging from "involving" to "non-involving"), the "content" of texts (ranging from "private" or "personal content," displayed in public contexts, to "non-private content"), and the "linguistic realisation" (ranging from the "language of immediacy" to the "language of distance") (Landert 2014, 28-35).

Another area of research on personalization in discourse studies is the analysis of the practice from the perspective of talk-in-interaction in the news interview, premised upon the groundbreaking work of conversation analysts (Clayman and Heritage 2004; Ekström and Patrona 2011; Lauerbach 2010, among others). While their focus is different, personalization continues to be associated with "markers of subjectivity and personal alignment" (Thornborrow and Montgomery 2010, 101) and the mediation of experiences from the private sphere in the public space, expressed in a form of "hybrid talk" (Ekström 2011; Ekström and Patrona 2011; Hutchby 2011). In view of the above, we may say that in political talk shows, the "hybrid talk" consists of (1) a combination of discursive registers (e.g., the expert type with colloquial-entertaining or confrontational registers, etc.), (2) the fusion of different television genres in the same format (journalistic inquiry, interview, satire, etc.), and/or (3) the integration of online communication into the media format (e.g., Facebook as a resource for the interactive dimension of the talk show). We notice that, in many of the existing studies, the analysis of personalization is mostly linked with the styles of various show hosts (Fairclough 1995) and with the politicians' management of their self-image via broadcast talk (Hamo et al. 2010). There are fewer studies that examine personalization in what regards the journalists' enactment of "critical" stances toward politicians (De Smedt and Vandenbrande 2011; Ekström 2011; Hutchby 2011), and, correspondingly, the influence of these practices on the ways in which public issues are built, and the interaction between politicians, talk show participants, and viewers is shaped (Lauerbach 2010).

In this article, we demonstrate that in Romanian political talk shows, the personalization of the journalist's discourse produces specific practices for the performance of the role of "critical political journalist" and this discursive mechanism is the main principle of ordering the interactional exchange in the political talk shows analyzed.

\section{Research Design and Methodology}

Our analytical framework is primarily derived from the French School of dispositive analysis in television studies (Charaudeau [2005] 2011; Lochard 2006) rooted in the Foucauldian paradigm. From this perspective, talk shows strategically incorporate heterogeneous, socially regulated practices, so that a "space of interaction" for the protagonists and the public is created. They are constituted through the enactment of (1) the communication project of the media (broadcast talk results from strategic choices made by producers, as part of their daily practices, and by the editorial policy of the TV channel), (2) the interactional strategies of the participants in the talk show (they have specific stakes in the discursive exchange, which have to be met within the framework predefined by the media), and (3) the shared practices, discourses, and symbolic contexts that are routinely salient in the media public spheres and in 
everyday life. It follows that talk shows can be analyzed as dispositives of symbolic power, triggering roles, status, interactional positions, and a space of visibility for the actors, events, and issues assessed by the television channel. On one hand, the media dispositive "structures the situation in which the linguistic exchanges unfold, by organizing them according to the places occupied by the interlocutors, the nature of their identity, the relationships established among them in view of a certain goal"; on the other hand, it "depends, for its functioning, upon the material conditions in which the linguistic exchange takes place" (Charaudeau 2005, 41, authors' translation). The verbal and visual modes employed in the televisual talk show are therefore integral to this ensemble of elements through which the communication project of a particular TV channel is put into practice.

We will closely examine how the role of critical political journalist is enacted in two Romanian talk shows broadcast on a private twenty-four-hour news and political commentary TV channel, Realitatea TV, starting from the observation that personalization plays a crucial part in the process. For this purpose, we have devised an analytical framework which is built on dispositive analysis, while integrating insights from the analysis of talk-in-interaction in political interviews (Clayman and Heritage 2004; Ekström and Patrona 2011) and from the discursive, textually oriented analyses of personalization (Fairclough 1994, 1995; Landert 2014), as presented in the "Personalization in Politics, Media, and Discourse" section. The framework includes the following dimensions along which the talk show as dispositive is produced:

1. The communication contract: the predefined framework of the talk show, in its regular features;

2. The interactional dynamics: a set of sequences encompassing (i) the question design; and (ii) the journalist's statements of accountability, correlated with the participants' answers;

3. Visual practices and modes of visualization.

The interplay of these dimensions creates a space of interaction among journalist, guests, and the public, which is regulated by the personalization of the journalist's status. With this in view, we will identify the resources of personalization deployed by the journalist within the talk show: (1) the incorporation into the talk show/media sphere of content from the private, nonpublic sphere (personal experiences, emotions, ideological preferences, collective opinions/shared knowledge, portrayals of ordinary people or public persons, including at a visual level, etc.); and (2) the linguistic realizations specific to a conversational mode, which can be mobilized strategically to indicate the journalist's construction of various positionings or of a power relationship with the interlocutors and viewers (informal, colloquial language, first- and secondperson pronouns, enunciation strategies, rhetorical questions, imperatives, etc.) (see also Landert 2014 for the categories of "content" and "linguistic realisation").

We have analyzed in depth two editions of the talk shows Jocuri de putere (Power Games, June 17, 2014, hosted by Rareş Bogdan) and Ediție specială (Special Edition, January 7, 2014, hosted by Dorin Chioțea), produced and broadcast by Realitatea TV. 
Both editions are concerned with the topic of labor migration (the opening of the European labor market for Romanians and Bulgarians, on January 1, 2014).

\section{Findings and Discussion}

\section{The Romanian Political Talk Show in the Postcommunist Public Sphere}

In Romania, a media culture of the talk show has gradually developed after the fall of communism in 1989, the talk show coming to be regarded as a true institution and a resource for public debate. The genre has seen a number of reconfigurations in terms of formats, thematic repertoires, and journalist roles, as a result of increased marketization, as well as broader institutional transformations. Thus, in the 1990s, in the first years of democracy, in a social context largely dominated by political cleavages, the talk shows hosted by commercial televisions became an alternative to the debates held on public television, seen as biased in favor of the elites in power. Considered to be more authentic, the talk shows on private TV channels entered the social imaginary as arenas or "tribunes" that conferred a different type of visibility to politics. This public perception came from the deregulated character of the formats: for example, the moderators were free to extend the duration of the show to several hours if they assessed that the urgency of the situation required it.

Starting in 1996, important changes occurred in the economy of the genre, due to the expansion of private televisions and the emergence of a competitive environment (Beciu 2011; Lazăr 2008). The effects were an increase in the commercialization of political journalism, in conditions of media pluralism. A marked tendency was the proliferation, especially after the year 2000, of commercial twenty-four-hour news TV channels, some of which acquired distinct identities on the basis of the media discourse they practiced (providing information and political commentary/debate). These competing TV channels would cultivate various forms of political bias and even partisanship, so that, over the past decade, the television sphere has become even more polarized, split between televisions that take on an explicit positioning toward the power or the opposition. Nowadays, the commercial TV channels constitute a symbolic territory that grants visibility to the politicians who are supported by the establishment of the channel, while fiercely criticizing the politicians from the opposing camp. Of course, these practices cannot be disentangled from the relations of influence between the ownership of large media trusts and the political sphere, some media owners being at the same time political party leaders.

However, since 2012, the dominance of partisan, populist journalism has been challenged by the creation of a private twenty-four-hour news television, Digi TV, which has already become a landmark in Romanian political journalism and which distinguishes itself through a neutral mediation of politics, where nonadversarialness is the norm. Even though such talk shows, in which journalists are critical, but within the limits of deliberative and equidistant interaction, are present in the landscape of commercial television, confrontational talk shows, characterized by sensationalism, negativism, and personalization, retain their centrality. They enjoy enormous popularity 
among their publics, which invests the host channels with the status of strategic actors in relation to the political environment and to various sources. The talk shows we have analyzed come at this stage in the development of the Romanian political talk show.

\section{Predefined Practices in Two Romanian Political Talk Shows}

Power Games, broadcast on Realitatea TV, deals mainly with issues on the current political agenda, as well as with broader topics related to identity (e.g., "we" as political and moral national community, various scenarios about the political future of the country having to cope with a political class that does not assume any responsibility, the crisis of role models in society, etc.). It is a highly personalized talk show, especially through the figure of the journalist-moderator, who has risen to fame along with the show, since its beginnings in 2013. The predefined framework relies on a typology of themes and on a specific interactional relationship between journalists and participants. Power Games reproduces a meta-discourse about politics from the perspective of moral principles, patriotism, and a very strong engagement with politicians in terms of exerting pressure upon them on behalf of "us," Romanians. As a trend, it provides visibility to actors enjoying symbolic capital. Thus, in most programs, four to six famous journalists and/or experts are invited as permanent guests to interpret the current political events. Another formula of the participation framework features the host journalist and one single guest considered of moral character and good reputation (they may be politicians, but most are intellectuals, artists, experts). The host can also take live phone calls from politicians/policy makers. What we notice as a characteristic of the talk show, in what concerns participation and social identities, is a "symbolic asymmetry" (Lochard 2006) built on power relationships between the media (the journalist) and the public, as well as between the journalist and the studio guests. As a constant trait, the moderator uses an authoritarian discourse toward the political class, strongly denouncing abuses and lack of accountability.

The second talk show, Special Edition, from the same TV channel, Realitatea TV, features types of participants similar to those of Power Games: guest journalists, experts, or a host/moderator and one guest, mostly a public intellectual or a politician. As stated on the Realitatea TV site, the show is dedicated to a thorough analysis of "sudden events of significant public interest," which "have been on the front page for days." The talk show amalgamates agenda themes or topics that give guests the opportunity to assess "the state of society" (various moments of "crisis") and discuss possible recovery scenarios.

The two talk shows are also connected in other ways, each moderator promoting both shows or participating as a guest in the other talk show. It is indeed a characteristic of the commercial TV channels in Romania that prime-time political talk shows are publicized by the entire TV team and that the journalist-moderators notify the audience that they share the same standpoints as regards the political power and opposition parties. This common discursive/ideological positioning of the journalists is likely to buttress the institutional status of these channels as actors in the political field. 
In the following sections, we show how, through various mechanisms of personalization, the journalist-moderators acquire, within these two talk shows, particular identities or micro-roles that are subsumed to and, at the same time, strengthen the role of critical journalist.

\section{The Journalist's Role as Interpellator: Watchdog, Engaged Citizen, and Persona}

The edition of the talk show Power Games that we have analyzed questioned the xenophobic stance against Romanian migrants taken by the UK Independence Party leader, Nigel Farage, and the violent incidents that occurred in Italy and France in June 2014, whose victims were Romanians. The journalist-moderator addressed these topics as part of a trend that emerged in the Romanian media especially after the year 2013, in the context of various public statements in the destination countries on an upcoming event (January 1, 2014): the lifting of restrictions for Romanian and Bulgarian workers and the presumed intensification of the economic immigration from these states.

First of all, the journalist-moderator initiates the discursive exchange between him and the participants (experts in the studio and politicians who phone in during the talk show) with a specific mode of enunciation - interpellation - that is summoning an explanation from the interlocutor about an issue for which he or she is considered responsible. Thus, journalists make it their mission to hold particular interlocutors accountable (e.g., decision makers). In this Power Games edition, interpellation takes the form of a virulent monologue, a quasi-autonomous discourse about the politicians' inaction regarding the most recent incidents involving Romanian migrants. The moderator keeps turning to the camera to vent his anger against politicians in front of the audience and to perform both the role of a journalist-persona and an engaged citizen who denounces the lack of political responsibility toward Romanian migrants. He endorses this posture through a strategy of personalization which consists of correlating his own affective reactions, generally expressed in the first person, with his status ("me as a Romanian," "me as a journalist," etc.):

For me, a question still remains; of course, it is all very well that the president of Romania is concerned with what happens in Lugansk or on the border between Ukraine and Russia, but, dear viewers and Mr. President, for me, as a citizen of Romania, for me, as a Romanian, what happened to that young man, 16 years of age, on the outskirts of Paris is very serious...

It hurts me, as a Romanian, as a journalist, not to see any reaction from the Romanian authorities ... I am still waiting for the reaction of the president of Romania.

I repeat, the Romanian Parliament, reassembled today, the Senate, in extraordinary session, no reaction, the Romanian Presidency, no reaction, the Romanian PM, with his large Cabinet, no reaction. I wonder-don't you care about Romanians at all? 
The journalist positions himself in a power relationship with the politicians and the public, as well as with his guests, revealing a direct, intense engagement in the appraisal of the situation, from which he can call on the authorities to react. With the help of long, monological sequences, strewn with rhetorical questions and expressions of emotion, building up toward anger, the moderator attempts to set the agenda for political action (Clayman and Heritage 2004, 197). In constructing what could be considered a "belligerent" stance, the talk show host draws upon a combination of "evaluation and advocacy" (Hutchby 2011, 124): (1) evaluation in the first person, from a multitude of overlapping roles — "for me, as a citizen of Romania, for me, as a Romanian"; "it hurts me, as a Romanian, as a journalist"; (2) advocacy, in the implicit demands that the Romanian authorities should have an official reaction to the event- "I am still waiting for the reaction . .."; "I repeat"; "I wonder-don't you care about Romanians at all?" By using this mode of personalization, the journalist justifies the questioning of those deemed responsible on the basis of his interpretation of the unfolding events. The traditional practice through which the journalist defines himself as a representative of the public opinion, by invoking what the ordinary person or citizen "expects" from the political class, what Clayman and Heritage $(2004,171)$ call being a "tribune of the people," takes here a significantly different form: the journalist substitutes his opinion for the public opinion in the sense that it is "his" analysis of the facts and "his" expectations from politicians that symbolically become the public opinion ("I wonder-don't you care about Romanians at all?"). This, moreover, puts him in a position of authority toward the target of his criticism. We witness thus in Romanian talk shows what Hutchby, in his analysis of the Hybrid Political Interview, characterizes as an enactment of "tribuneship" through the journalist's "explicit foregrounding of agency," one of the instances where the adversarial journalistic style acquires that extra-dimension of "doing non-neutral" (Hutchby 2011, 132-33, emphasis in original; Figures 1 and 2).

Second, the shift from the interpellation of politicians to the interaction with the studio guests is made through short confessions, critical comments, or appraisals that preface the questions and, importantly, show the journalist's inside knowledge of the political scene. We are dealing here with another strategy of personalization embedded in the question design: the personalization of the journalist's status in the media-political field of power. It aims to establish the host's reputation as a journalist who is very well connected with power actors:

... I talked to his Excellency ten days ago when we attended our Romanian player Simona Halep's outstanding tennis match at Roland Garros, an admirable man, this is not the first time I've talked to him . . .

The journalist describes himself in roles pertaining to the private sphere, but which have public relevance in the context of the show ("I'm a man who travels around the world"), and draws the profile of politicians ("an admirable man, this is not the first time I've talked to him"; "what to expect from Mr...., the poor man"). In addition to showing off the journalist's social capital, this manner of presenting official representatives in private circumstances enables viewers, according to Landert (2014, 241), to 


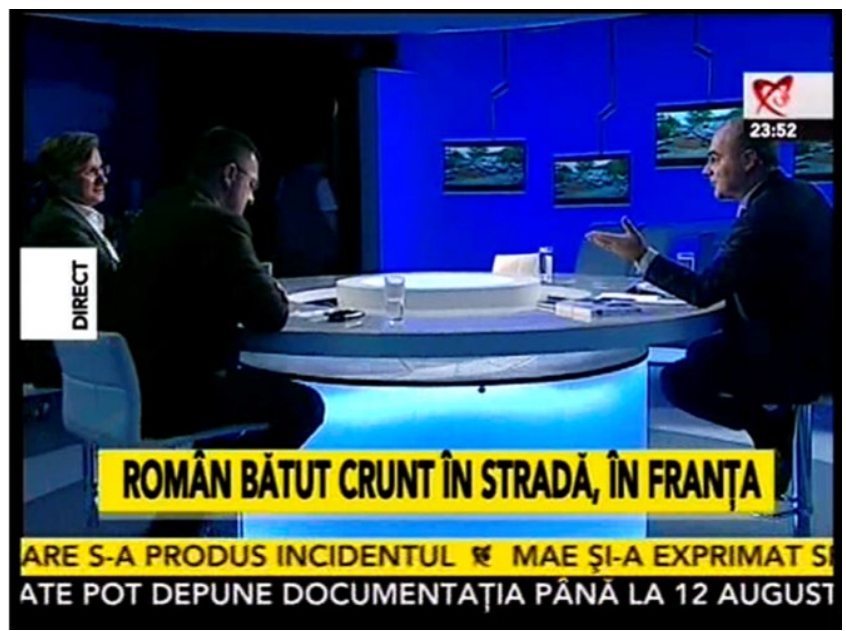

Figure I. Power Games: The layout of the studio.

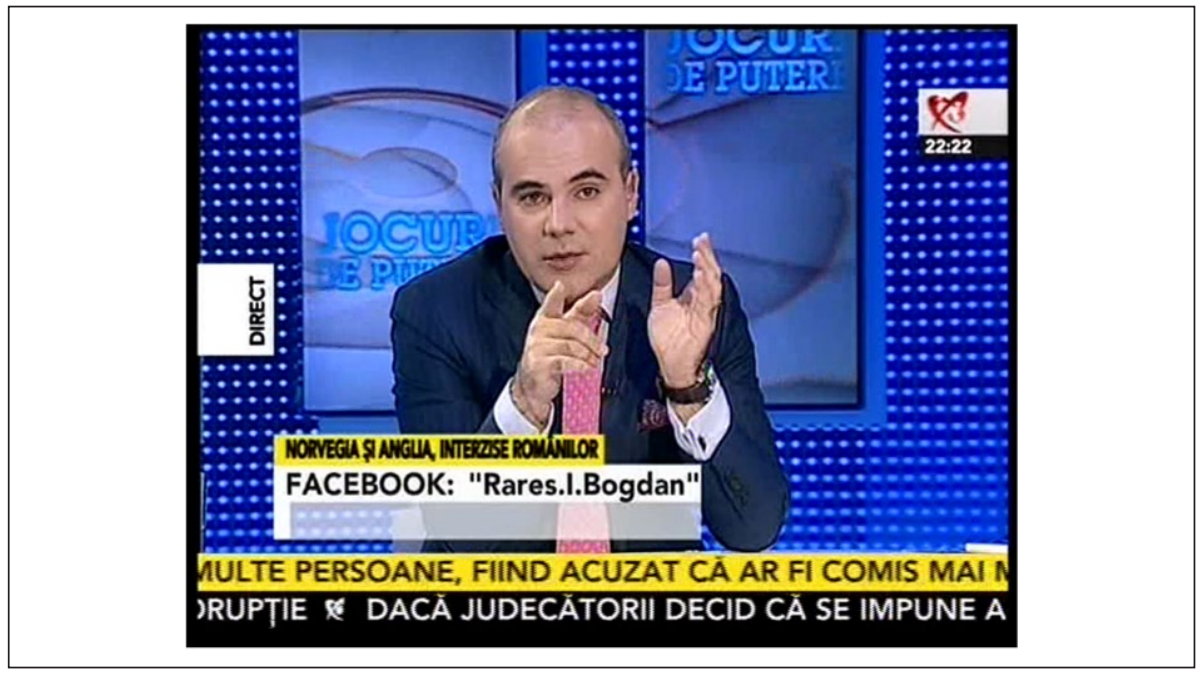

Figure 2. Power Games: A close-up with the talk show host interpellating the authorities.

"adopt the perspective of the journalist, who is meeting these public figures in person," serving as a strategy for audience involvement. On the contrary, in the dialogue with his studio guests, the journalist displays a carefully managed deference, which contrasts visibly with the vehemence of his interpellation of decision makers: 
Professor N., you know very well what has happened, you are well familiar with the negative, peripheral part of the large Romanian community in Italy . . Tell me, why is this happening?

Two axes of interaction are constituted through his discursive behavior: one not only with generic interlocutors (politicians, institutions, the public itself) but also with nominated ones (certain politicians/decision makers, members of the public), whom he engages by looking directly into the camera and using rhetorical questions, critical comments, as well as calls to action and direct questions (also addressed to the public); the other, centered around the interaction with the guests, whom the moderator addresses by means of a deferential tone. A symbolic hierarchy of interlocutors is thus established. During the talk show, the host switches between axes and alternates the roles he takes. Personalization provides the discursive support for the shifts from one mode of interaction to the other, and, simultaneously, from one perspective on the issue (political responsibility) to another (the migrants, a vulnerable community), as shown in the example above.

The questions put to the studio guests invite them to adhere to the critical viewpoints expressed by the journalist. The guests, however, do not always adopt the critical interpretation built in the host's questions and may resort to avoidance strategies. As a result, we witness the emergence of relatively autonomous discourses (the journalist's, the guests'), also sustained by the lengthy interventions of the interlocutors, a characteristic of Romanian talk shows.

Visual practices such as electronic captions at the bottom of the screen consolidate the moderator's perspective on events, preserving and extending his interpellative tone through the general evaluations they introduce, such as "Norway and Britain out of bounds for Romanians," "Who do Romanians bother in the EU?" The message of electronic captions is further supported by images; for instance, an utterance like "The Romanians - targets of EU extremists" is displayed together with scenes from documentaries or reportages, which depict a particular category of migrants: people living in poverty and committing crimes of all sorts. As a form of media populism, the practice of screen display also has the function to capture the public's attention by presenting the negative impact of the events on "us" (inclusive "we") or by asking rhetorical questions that point to the existence of hidden scenarios or behind-the-scenes maneuvers. The electronic captions are formulated in such a way as to get the viewers engaged (Landert 2014) through identification with a community that is vulnerable in relationship with the actions of politicians.

The visual elements in the talk show lead to a dramatized televisual meta-discourse, likely to legitimize the interpellations voiced by the journalist in what concerns the politicians' responsibility toward the migrants in the destination countries and, in general, the Romanians' status in the European Union.

\section{"What Actually Happens": The Journalist as an Ordinary Person}

The Special Edition we have looked at was broadcast on Realitatea TV in the first week after the official lifting of restrictions for Romanian and Bulgarian workers. At the time, the Romanian press mediated intensely the first public opinion reactions to this event in 


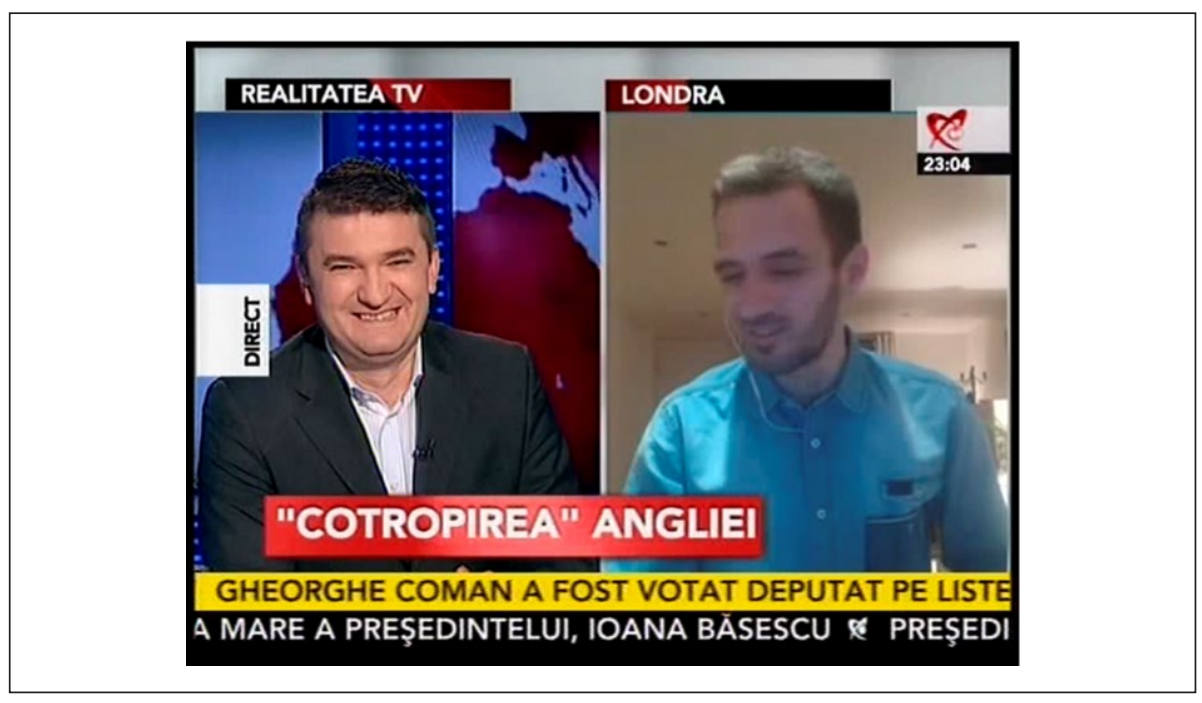

Figure 3. Special Edition: Friendly exchange between talk show host (left) and guest from London (right), by Skype.

the United Kingdom (media, politicians, ordinary people), especially British tabloid articles and the statements of far right-wing leaders who had warned against a possible U.K. "invasion" by Romanian and Bulgarian workers. This edition also tackles the negative reaction of the British press to the granting of full access to the U.K. labor market for Romanians and Bulgarians. The journalist-moderator calls into question the extent to which the Romanian migrants have a negative image in the United Kingdom, considering that the phenomenon deserves a more in-depth analysis.

To begin with, the host's questions prompt the testimonies of guests who are well acquainted with British society, being able to assess, through the lens of personal experience, the public attitudes toward Romanian migrants in Britain (one of them, for example, is a British expat living in Romania; another is a Romanian journalist and writer who lives in London). They are therefore assigned the role of credible witnesses, who can cast light on the British public attitudes and reactions to Romanians. The discursive exchange is built on testimonial questions and conducted in an informal manner by the moderator, who sets up a framework of convivial interaction with the participants, underlined by his repeated use of the appellative "friends" and the preference for a first-name basis among interlocutors. The moderator's interventions are minimal; they do not regulate the discursive exchange, but rather favor a relaxed conversation, blending humor, irony, and politics in the discussion of sensitive issues, such as the British public reaction to migration.

The chief strategy of personalization consists of projecting the image of the journalist-as-ordinary-person. The manner of address, the informal language, and, in particular, the formulation of questions and comments, including jokes and short narratives, situate the participants in the space of everyday life, both as actors and engaged observers (Figure 3). 
The full entrance into the private sphere, supported by the talk show, is the means of bringing in a new perspective on the topic of Romanian migration to the United Kingdom. It is a perspective that will be counterposed to what is regarded as the dominant British public discourse on the issue. The moderator's performance of the role of critical journalist, in this case, would not be possible in the absence of the personalized role of journalist-as-ordinary-person, which extends to the other participants, as well. The two roles are therefore thoroughly intermeshed. This hybridization can first be noticed in the manner in which the talk show host formulates the questions, as a naïve observer who replicates shared knowledge. He asks one of the guests (the Romanian journalist and writer working in the United Kingdom, connected by Skype) to tell his "story" as a Romanian migrant who looks for a job in London: "Is it written on your forehead that you are a second class citizen? How do you and your friends see these things?" It is a posture that allows the journalist to build a consensual point of view (Fairclough 1995), in the sense that the image of Romanians and of the country is more than a sensitive public issue; it is an aspect that "we all know" because we experience it in our everyday lives. Starting from this fact, the journalist raises the issue of the politicians' responsibility for implementing appropriate policies and taking action regarding the Romanian migrants in the EU countries. What draws attention is the modality of voicing critical reactions toward politicians: the introduction of the ordinary citizen's perspective in the personalization of interaction leads to an indirect manner of expressing criticism, via the guests' personal experience, shared with and by the talk show host. This way of invoking political responsibility assumes the fact that political action is inappropriate:

Journalist-moderator: To what extent do you feel protected in London by the authorities from Bucharest, by our embassy there, by the Romanian government?

The same effect of given reality can be found in the journalist's questions or comments that deconstruct stereotypes and prejudice about the British public opinion on migration. Put another way, this type of personalization permits the moderator to introduce in his questions certain appraisals as if they were taken for granted:

Journalist-moderator to guest (a British expat in Romania): D., how is this problem of the Romanians' and Bulgarians' "invasion" seen by your friends in the UK, by the ordinary person? What do your parents think? Your brothers, your relatives, your neighbors there, people you keep in touch with? Beyond what the tabloids, the television reportages say...

British expat: I've been posting a lot of the negative press and the positive press on my FB page and I've got lots of responses ... but the people there make jokes about the Daily Mail. My family do not care, we really do not care about this subject. . . . As far as in general is concerned, most of the people I know don't care. . . .

Journalist-moderator: So, as you said, D., not all Britons dislike Romanians; most of them see us as a resource needed to do quality work, as an inventive and a serious people. 
At certain moments during the interaction, while the guests present their positive experiences in the United Kingdom concerning the perception of Romanians, the screen displays repeatedly negative stereotypes about Romanian migrants, for example, Romani singers on the streets of London. By contrast to the edition from Power Games that we have analyzed, where the images reinforce the verbal content, here they reinforce exactly what the verbal exchanges are apparently aimed at dismantling, that is, the general understanding that Romanians have a negative image in the United Kingdom. This mode of personalized visualization, centered on social actors in stereotypical roles, is intended to convey authenticity, connect publics to the unfolding events, and engage them by stirring up interest and emotion, due to the evaluation built in the images and the impression of direct experience they give (Landert 2014, 97-100).

The participants' arguments are put forward as an indirect counter-discourse to the allegedly dominant British media discourse. They do not always explicitly refer to the British press, but give answers in line with the questions asked by the moderator, which hint at the fact that the tabloid press is a problem for "us all":

Journalist-moderator to guest (the Romanian journalist): Are you proud to be a Romanian when walking on the streets of London? [generic "you," Authors' note]

Guest: I'm not sure if proud, but it's not a source of distress, either [laughing mildly]. About a week and a half ago I went to a farmers' fair, somewhere in the northern part of London, and at the entrance to the fair there was a Romanian Roma, and the people at the fair, the salespeople, did not complain about his presence, but about the fact that he only knew one song with which he had driven them crazy for 3, 4 hours, playing it incessantly. The Romanians can be seen especially on the Westminster Bridge, between the Parliament and the London Eye. Many of them play the shell game ... The Romanians, how shall I put it, it's somehow disturbing what you can see in the press here because they only present cases that may harm the British people, beggars, thieves, very rarely do you see articles about the hundreds of engineers, the hundreds of doctors who are here and work and who do a very, very good job.

The question put by the moderator contains the presupposition that on the streets of London, one can see certain groups of Romanian migrants whose behavior is usually considered to tarnish the Romanians' good reputation. The guest offers an answer in view of the implicit content of the question. Even though it is intended to deconstruct dominant public discourses on this issue in Romania and the United Kingdom, at the same time it reproduces certain negative stereotypes about these vulnerable categories of migrants, which are not at all problematized; on the contrary, given the informal layout of the talk show, such opinions are easily conveyed as common sense views. In addition, the use of the second-person pronoun, either the direct, referential "you," addressed to the guests, normally exclusive of the audience, or the generic "you," creates audience engagement in building consensus because it invites the viewers "to identify with the described positions" (Landert 2014, 227). The paradoxical outcome is that, while the talk show aims to demonstrate that not all the Romanians have a negative image in the United Kingdom, the consensual exchanges about Romanian beggars and criminals buttress stereotypical perceptions and indirectly attribute blame. 
In other sequences, the journalist-moderator and his guests take an explicit stance against the cases presented by the British tabloids, by adopting an ironic tone. They speak as ordinary readers, who can spontaneously bring up typified news themes from a sensationalistic media repertoire. The examples invoked acquire a pragmatic force, because they are introduced as shared knowledge among the interlocutors, who impersonate old friends:

Journalist-moderator to guest (Romanian in-studio guest): Keep your thought, D., and let us laugh a little, let us have a look at this story about the goat ["In January, the only thing left will be the goat," the headline of an article published by the Daily Mail about the potential emigration of an entire Romanian village, our note] which the British tabloids have cooked up, let us have some fun, yeah? ...

Guest: But do you remember that story about the attempted kidnapping of Victoria Beckham? All sorts of fabrications.

The relationship between the journalist and the audiences is similarly personalized and this can be noticed throughout the talk show, whenever the journalist attempts to mobilize an active and connected public, invited to access the moderator's Facebook page to share personal stories, relevant for the public opinion in Britain on the topic of Romanian immigrants. The moderator engages in a dialogue with the public in his own name, urging viewers, including the ones in the United Kingdom, to give examples of the Romanian migrants' contribution to the British economy and, hence, of their positive role in the United Kingdom. In this manner, the moderator symbolically defines the viewers as talk show participants who are assigned responsibility for refuting or confirming the stereotypes about the way "we" are perceived: "Look what D.M. has written to me: 'Thousands of Romanians work in Britain without disturbing anyone; I have a friend who has a successful company in London in which seven hundred Romanians are legally employed.",

Personalization is a central discursive strategy in the talk show discussed here: first, it counterposes the everyday perceptions in Romania and the United Kingdom to the public discourses about Romanian migrants in the two states, both at the level of content (the opinions of friends, family, ordinary citizens, and viewers) and at the level of discursive realization (informal dialogue, colloquial tone, jokes, short narratives); second, by drawing on common sense views and shared knowledge, it naturalizes precisely what it seeks to deconstruct, namely, the idea that Romanian migrants are perceived negatively because of particular individuals/groups, who do not abide by British legislation.

\section{Conclusion}

We have examined how personalization is employed as a resource for the enactment of the role of "critical political journalist" by taking into account the case of two types of political talk show on Romanian commercial television. This media genre has developed specific characteristics, for example, the symbolic authority of a journalist-moderator 
who assumes advocacy stances, as different from the "non-neutral" style of interviewing traditionally encountered in the Anglo-American model of political journalism (Ekström and Patrona 2011). Importantly, Romanian talk show hosts draw upon personalization for the performance of this role, within a media dispositive that fully accommodates the practice.

In our analysis, we have identified two patterns of personalization. In the first pattern, the role of critical journalist relies on forms of involvement that combine the perspectives of watchdog, engagement, and advocacy. In the second pattern, the chief mechanism of personalization consists of projecting the image of the journalist-asordinary-person. Within these patterns, the journalist combines different identities or micro-roles (citizen, ordinary person, public figure, engaged journalist, educator, vox populi), each of them contributing to the enactment of the journalist's critical role. Specifically, the journalists incorporate into the show "personal content" from different fields of action: the media-political field, the civic sphere, and the sphere of everyday life; this hybridization shapes the dynamics of interaction in the talk show, both in terms of the relationships established between journalists and their interlocutors, and the interpretations they give to the issues on debate.

In addition, our research has shown that the strategies of personalization, beyond their inherently persuasive function, provide ways of understanding the issues debated in televisual talk shows. By personalizing their status, journalists prescribe types of responsibility (political, collective, individual), modes of engagement for the audience, and naturalize events, contexts, and interpretations thereof. They introduce questions that point toward a certain interpretation or legitimize the existence of a dominant discourse in society on the topic under debate. Personalization enables journalists to perform the role of fully engaged public voices, which marks a shift from the expected position of talk show moderators as mere representatives of the public opinion.

The way in which personalization, as an ongoing trend in political journalism, is embedded in specific practices concerning the role of the journalist and, in particular, of the critical journalist requires cross-cultural analyses. Such analyses would constitute a relevant basis for understanding the implications of personalization in relation to the quality of broadcast political journalism.

\section{Declaration of Conflicting Interests}

The authors declared no potential conflicts of interest with respect to the research, authorship, and/or publication of this article.

\section{Funding}

The authors disclosed receipt of the following financial support for the research, authorship, and/ or publication of this article: This work was supported by a grant of the Romanian National Authority for Scientific Research, CNCS-UEFISCDI (project number PN-II-ID-PCE-2011-3-0968), Diaspora in the Romanian Media and Political Sphere. From Event to the Social Construction of Public Issues. 


\section{References}

Beciu, Camelia. 2011. Sociologia comunicării și a spațiului public [The Sociology of Communication and of the Public Sphere]. Iași: Editura Polirom.

Charaudeau, Patrick. (2005) 2011. Les médias et l'information: L'impossible transparence du discours [The Media and Information: The Impossible Transparency of Discourse]. 2nd ed. Bruxelles: De Boeck-Ina.

Charaudeau, Patrick. 2005. Le discours politique: Les masques du pouvoir [Political Discourse: Power Masks]. Paris: Vuibert.

Christians, Clifford G., Theodore L. Glasser, Denis McQuail, Kaarle Nordenstreng, and Robert A. White. 2009. Normative Theories of the Media: Journalism in Democratic Societies. Urbana: University of Illinois Press.

Clayman, Steven, and John Heritage. 2004. The News Interview: Journalists and Public Figures on the Air. Cambridge: Cambridge University Press.

Coleman, Stephen. 2013. "Debate on Television: The Spectacle of Deliberation." Television \& New Media 14 (1): 20-30. doi:10.1177/1527476411433520.

Corner, John, and Dick Pels, eds. 2003. Media and the Restyling of Politics: Consumerism, Celebrity and Cynicism. London: Sage.

de Beus, Jos. 2011. "Audience Democracy: An Emerging Pattern in Postmodern Political Communication." In Political Communication in Postmodern Democracy: Challenging the Primacy of Politics, edited by Kees Brants and Katrin Voltmer, 19-38. Basingstoke: Palgrave Macmillan.

Debrett, Mary. 2015. “'Tools for Citizenship?' Public Service Media and Civic Engagement: An Australian Case Study." Television \& New Media 16 (6): 557-75. doi:10.1177/1527476414557951.

De Smedt, Eva, and Kristel Vandenbrande. 2011. "Political Television Formats as Strategic Resources in Achieving Journalists' Roles." In Talking Politics in Broadcast Media: CrossCultural Perspectives on Political Interviewing Journalism and Accountability, edited by Mats Ekström and Marianna Patrona, 75-93. Amsterdam: John Benjamins.

Ekström, Mats. 2011. "Hybridity as a Resource and Challenge in a Talk Show Political Interview." In Talking Politics in Broadcast Media: Cross-Cultural Perspectives on Political Interviewing Journalism and Accountability, edited by Mats Ekström and Marianna Patrona, 135-55. Amsterdam: John Benjamins.

Ekström, Mats, and Marianna Patrona, eds. 2011. Talking Politics in Broadcast Media: Cross-Cultural Perspectives on Political Interviewing Journalism and Accountability. Amsterdam: John Benjamins.

Fairclough, Norman. 1994. "Conversationalization of Public Discourse and the Authority of the Consumer." In The Authority of the Consumer. Lancaster University Center for the Study of Cultural Values, edited by Russell Keat, Nigel Whiteley, and Nicholas Abercrombie, 235-49. London: Routledge.

Fairclough, Norman. 1995. Media Discourse. London: Edward Arnold.

Hallin, Daniel C., and Paolo Mancini. 2004. Comparing Media Systems: Three Models of Media and Politics. Communication, Society and Politics. Cambridge: Cambridge University Press.

Hamo, Michal, Zohar Kampf, and Limor Shifman. 2010. "Surviving the 'Mock Interview': Challenges to Political Communicative Competence in Contemporary Televised Discourse." Media, Culture \& Society 32 (2): 247-66. doi:10.1177/0163443709355609.

Hutchby, Ian. 2011. "Doing Non-neutral: Belligerent Interaction in the Hybrid Political Interview." In Talking Politics in Broadcast Media: Cross-Cultural Perspectives on 
Political Interviewing Journalism and Accountability, edited by Mats Ekström and Marianna Patrona, 115-35. Amsterdam: John Benjamins.

Jebril, Nael, Eric Albæk, and Claes de Vreese. 2013. "Infotainment, Cynicism and Democracy: The Effects of Privatization vs Personalization in the News." European Journal of Communication 28 (2): 105-21. doi:10.1177/0267323112468683.

Landert, Daniela. 2014. Personalisation in Mass Media Communication: British Online News between Public and Private. Amsterdam: John Benjamins.

Lauerbach, Gerda. 2010. "Manoeuvring between the Political, the Personal and the Private: Talk, Image and Rhythm in TV Dialogue.” Discourse \& Communication 4 (2): 125-59. doi:10.1177/1750481310363980.

Lazăr, Mirela. 2008. Noua televiziune și jurnalismul de spectacol The New Television and Sensational Journalism. Iași: Editura Polirom.

Lochard, Guy, ed. 2006. Les débats publics dans les télévisions européennes Public Debates onEuropean Television Channels. Paris: L'Harmattan.

Mădroane, Irina Diana. 2015. "Campaign Journalism on Romanian Televisions: Towards a Normative View of Advocacy in the Media." Revista română de sociologie XXVI (5-6): 415-30.

Mancini,Paolo.2011."Leader,President,Person:LexicalAmbiguitiesandInterpretiveImplications." European Journal of Communication 26 (1): 48-63. doi:10.1177/0267323110394835.

Musso, Pierre. 2009. Télé-politique. Le sarkoberlusconisme à l'écran. Tele-Politics. Sarkoberlusconism on Screen. La Tour d'Aigues: Editions de 1'Aube.

Stamper, Judith, and Kees Brants. 2011. "A Changing Culture of Political Television Journalism." In Political Communication in Postmodern Democracy: Challenging the Primacy of Politics, edited by Kees Brants and Katrin Voltmer, 111-25. Basingstoke: Palgrave Macmillan.

Thornborrow, Joanna, and Martin Montgomery. 2010. "Special Issue on Personalization in the Broadcast News Interview." Discourse \& Communication 4 (2): 99-104. doi:10.1177/1750481310364332.

Turner, Graeme. 2009. Ordinary People and the Media: The Demotic Turn. London: Sage.

Van Aelst, Peter, Tamir Sheafer, and James Stanyer. 2011. "The Personalization of Mediated Political Communication: A Review of Concepts, Operationalizations and Key Findings." Journalism 13 (2): 203-20. doi:10.1177/1464884911427802.

Van Santen, Rosa A. 2012. "Popularization and Personalization: A Historical and Cultural Analysis of 50 Years of Dutch Political Television Journalism." PhD diss., University of Amsterdam. http://dare.uva.nl/record/1/372119 (accessed October 25, 2016).

\section{Author Biographies}

Camelia Beciu is a professor at the University of Bucharest and a researcher at the Institute of Sociology of the Romanian Academy. She has published extensively on the media construction of public issues, political communication, and the public sphere.

Mirela Lazăr currently works as a professor at the University of Bucharest (Romania). Her main areas of interest are discourse analysis, media discourse, European journalism, and diasporic identity.

Irina Diana Mădroane is a senior lecturer at the West University of Timişoara. She is specialized in critical discourse analysis, media discourse, and identity construction in public discourse. 